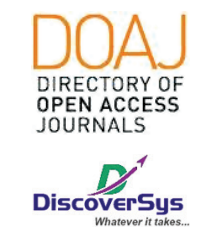

Published by DiscoverSys

\section{Pengaruh kebiasaan merokok terhadap kejadian disfungsi ereksi pada petugas keamanan di Universitas Udayana Sudirman}

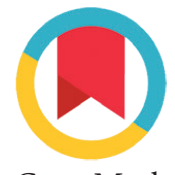

CrossMark

\author{
Tifania Melucha Miguel Leong, ${ }^{1 *}$ I Made Oka Negara, ${ }^{2}$ Yukhi Kurniawan ${ }^{2}$
}

\title{
ABSTRACT
}

Introduction: Smoking habits are behaviors that are now still seen in various country and these behaviors are really difficult to eliminate. Each cigarette dangerous chemicals like nicotine that can be effect to health especially smokers, one of this effect is erectile dysfunction. In this Study, the aim was to determine how much influence smoking habits can affect to erectile problem in security officers at Udayana University Sudirman. Methods: This is a cross-sectional descriptive study that was conducted at Udayana Universitas Sudirman with 10 participants and obtained from filling IIEF-5 questionnaire (International Index of Erectile
Dysfunction) and active smoker questionnaire that were distributed directly to the participants.

Result: The results of this study was shown that almost $40 \%$ security officers had mild erectile dysfunction. This study is observer from NonProbability Sampling especially in convenient sampling to look the effect of smoking habits that against erectile dysfunction.

Conclusion: The security officer at Udayana University in Sudirman with smoking habits almost all experienced erectile dysfunction with different categories of erectile dysfunction.

Keywords: smoking habits, erectile dysfunction.

Cite This Article: Leong, T.M.M., Negara, I.M.O., Kurniawan, Y. 2019. Pengaruh kebiasaan merokok terhadap kejadian disfungsi ereksi pada petugas keamanan di Universitas Udayana Sudirman. Intisari Sains Medis 10(3): 844-846. D0I: 10.15562/ism.v10i3.498

\section{ABSTRAK}

Latar Belakang: Kebiasaan merokok merupakan perilaku yang sekarang masih terlihat di berbagai negara dan perilaku tersebut sulit untuk menghilangkannya. Pada setiap batang rokok terkandung zat kimia yang berbahaya kesehatan para perokok dan salah satunya adalah Disfungsi Ereksi. Penelitian ini bertujuan untuk mengetahui seberapa besar pengaruh kebiasaan merokok terhadap kejadian DE pada petugas keamanan di Universitas Udayana Sudirman.

Metode: Jenis penelitian ini adalah Cross-sectional Descriptive Study. Penelitian ini dilakukan di Kampus Universitas Udayana Sudirman dengan jumlah responden 10 orang dan didapatkan dari pengisian kuesioner IIEF-5 (International Inde of Erectile Function) dan kuesioner perokok aktif yang dibagikan secara langsung pada responden.

Hasil: Dari hasil penelitian ini, menunjukan bahwa dari 10 petugas keamanan didapatkan $40 \%$ mengalami DE ringan. Di uji dari NonProbability Sampling khususnya Convenient Sampling terhadap pengaruh kebiasaan merokok pada disfungsi ereksi.

Simpulan: Petugas keamanan di Universitas Udayana Sudirman dengan kebiasaan merokok hampir seluruhnya mengalami disfungsi ereksi dengan kategori yang berbeda terhadap kejadian disfungsi ereksinya.
'Program Studi Pendidikan Dokter, Fakultas Kedokteran Universitas Udayana

2Departemen Andrologi dan Seksologi, Fakultas Kedokteran Universitas Udayana

${ }^{*}$ Correspondence to: Tifania Melucha Miguel Leong, Program Studi Pendidikan Dokter, Fakultas Kedokteran Universitas Udayana

tifaniamiguelleong@gmail.com

Diterima: 08-04-2019

Disetujui: 24-11-2019

Diterbitkan: 01-12-2019

\section{Kata kunci: kebiasaan merokok, disfungsi ereksi}

Cite Pasal Ini: Leong, T.M.M., Negara, I.M.O., Kurniawan, Y. 2019. Pengaruh kebiasaan merokok terhadap kejadian disfungsi ereksi pada petugas keamanan di Universitas Udayana Sudirman. Intisari Sains Medis 10(3): 844-846. D0I: 10.15562/ism.v10i3.498

\section{PENDAHULUAN}

Rokok merupakan gulungan yang berasal dari tembakau yang berbentuk panjang sebesar kelingking dan dibungkus oleh daun atau kertas. ${ }^{1}$ Secara umum rokok adalah salah satu bahan yang berbahaya di dunia dikarenakan olahan tembakau tersebut menghasilkan zat nikotin dan tar yaitu zat yang dapat menyempitkan arteri yang menuju ke penis, sehingga aliran darah dan tekanan darah menuju penis menurun. ${ }^{2}$
Berdasarkan WHO, mengatakan bahwa Indonesia merupakan peringkat-4 dalam jumlah perokok terbanyak di dunia dengan jumlah mencapai 141 juta orang. ${ }^{2}$ Saat ini, kebiasaan merokok sudah menjadi budaya di berbagai negeri bahkan di seluruh dunia. Setiap batang rokok dapat menghasilkan lebih dari 4000 bahan kimia beracun yang berbahaya, diantarannya nikotin, tar, karbon monoksida dan timah hitam. Kebiasaan merokok juga dapat memberikan 
dampak yang negatif bagi kesehatan seksual pria dan salah satunya adalah $\mathrm{DE} .^{3}$

DE adalah ketidak mampuan untuk mencapai atau mempertahankan ereksi dalam melakukan hubungan seksual dalam 3 bulan. ${ }^{4,5}$ Disfungsi ereksi memiliki berberapa faktor dari psikis maupun fisik dan salah satu faktor tersebut adalah kebiasaan merokok. Pada hasil survei Massachussetts Males Aging Study (MMAS) terdapat bahwa perokok adalah faktor yang memiliki resiko tinggi terjadinya DE sedang dan berat yang mencapai $24 \%$ dibandingkan dengan orang yang tidak merokok yang hanya memiliki resiko kurang lebih $14 \%{ }^{6}$

\section{METODE}

Penelitian ini merupakan penelitian deskriptif dengan pendekatan cross-sectional yakni. Penelitian ini dilakukan di Kampus Universitas Udayana

Tabel 1 Distribusi responden berdasarkan usia

\begin{tabular}{lcc}
\hline Usia & Jumlah & Presentase (\%) \\
\hline $32-35$ & 3 & 30 \\
$36-39$ & 4 & 40 \\
$45-55$ & 3 & 30 \\
Total & 10 & 100 \\
\hline
\end{tabular}

Tabel 2 Karateristik responden berdasarkan Jumlah Rokok perhari

\begin{tabular}{lcc}
\hline Jumlah rokok perhari & Jumlah Orang & Persentase (\%) \\
\hline$<1$ bungkus & 5 & 50 \\
1 bungkus & 4 & 40 \\
$>2$ bungkus & 1 & 10 \\
Total & 10 & 100 \\
\hline
\end{tabular}

Tabel 3 karakteristik responden berdasarkan lamanya mengkomsumsi rokok

\begin{tabular}{lcc}
\hline $\begin{array}{l}\text { Tahun } \\
\text { (Lamanya Merokok) }\end{array}$ & Jumlah orang & Presentase (\%) \\
\hline $1-10$ & 4 & 40 \\
$>20$ & 6 & 60 \\
Total & 10 & 100 \\
\hline
\end{tabular}

Tabel 4 Distribusi perokok berdasarkan perhitungan skor IIEF-5

\begin{tabular}{lccccc}
\hline Fungsi Ereksi & $\mathbf{3 2 - 3 5}$ & $\mathbf{3 6 - 3 9}$ & $\mathbf{4 5 - 5 5}$ & $\mathbf{N}$ & Persentase (\%) \\
\hline Normal & 0 & 1 & 0 & 1 & 10 \\
DE ringan & 1 & 2 & 1 & 4 & 40 \\
DE Sedang-Ringan & 0 & 1 & 2 & 3 & 30 \\
DE Sedang & 1 & 0 & 0 & 1 & 10 \\
DE Berat & 1 & 0 & 0 & 1 & 10 \\
Total & 3 & 4 & 3 & 10 & 100 \\
\hline
\end{tabular}

Sudirman pada bulan Maret 2019. Subyek penelitian adalah seluruh petugas keamanan yang merokok yang berusia dibawah 60 tahun dan bekerja di kampus Universitas Udayana Sudirman. Pengambilan sampel dilakukan dengan menggunakan metode Total sampling. Setelah subjek dipastikan masuk dalam kriteria penelitian, diberikan persetujuan secara lisan dan tertulis pada lembar inform consent.

Data pada penelitian ini menggunakan data primer dengan menggunakan kuesioner yang dibagikan dan diisi secara mandiri oleh respondenData yang telah terkumpul diolah dengan menggunakan aplikasi Microsoft Word dan SPSS, kemudian disajikan dalam bentuk tabel

\section{HASIL}

Berdasarkan analisis data tabel 1 dapat diketahui bahwa rata-rata usia responden paling banyak adalah 36-39 tahun, yaitu sebanyak 4 orang (40\%)

Berdasarkan tabel 2 di atas diketahui bahwa responden terbanyak yang dalam 1 hari merokok kurang dari 1 bungkus dengan jumlah banyak 5 orang $(50 \%)$

Berdasarkan tabel 3 di atas diketahui bahwa lamanya mengkomsumsi rokok adalah lebih dari 20 tahun berjumlah sebanyak 6 orang (60\%)

Berdasarkan tabel 4 diatas bahwa didapatkan 1 orang $(10 \%)$ tidak memiliki DE atau normal dan 4 orang $(40 \%)$ memiliki DE ringan.

\section{DISKUSI}

Berdasarkan hasil yang didapat $60 \%$ responden sudah memiliki kebiasaan merokok lebih dari 20 tahun. Jika kita lihat pada penelitian yang dilakukan oleh Jeanne (2016), status merokok laki-laki hipertensi usia 18-64 tahun di wilayah kerja Puskesmas Susut I, kecamatan Susut 1, Bangli didapatkan cenderung merupakan perokok aktif. ${ }^{7}$ Orang yang sudah biasa merokok, memang susah untuk menghentikannya. Karena rokok mengandung nikotin yang membuat perokok selalu ingin merokok lagi atau ketagian. ${ }^{8}$ Pada mantan perokok, durasi berhenti merokok memiliki hubungan linier yang signifikan dengan peningkatan kecepatan aliran arteri dan parameter kekakuan arteri kembali ke tingkat tidak signifikan setelah satu dekade berhenti merokok

Keseluruhan pada penelitian pengaruh kebiasaan merokok terhadap kejadian disfungsi ereksi pada petugas keamanan Universitas Udayana Sudirman, didapatkan hampir seluruh responden mengalami disfungsi ereksi dengan kategori yang berbeda yang diperlihatkan pada tabel yang di atas menunjukan bahwa distribusi perokok menurut 
hasil perhitungan skor Indeks Internasional Fungsi Ereksi (IIEF), berdasarkan kelompok umur, yaitu sekitar 1 orang tidak mengalami disfungsi ereksi atau dinyatakan normal sebanyak 1 orang $(10 \%)$, disfungsi ereksi ringan sebanyak 4 orang (40\%), disfungsi ereksi sedang-ringan 3 orang (30\%), difsungsi ereksi sedang 1 orang (10\%) dan disfungsi ereksi berat 1 orang (10\%). Dari hasil data tabel yang diatas berhubungan dengan faktor-faktor yang berpengaruhi disfunsi ereksi dan salah satunya kebiasaan merokok dan berberapa penelitian menyatakan bahwa pria yang memiliki kebiasaan merokok 1 pak rokok/hari beresiko $40 \%$ lebih tinggi terkena diasfungsi ereksi dibandingkan dengan pria yang tidak merokok. Dari jurnal Tabacco Control mengatakan bahwa pada 8000 pria Australia berumur 16-59 tahun yang merokok satu pak/hari beresiko 24\% terkena disfungsi ereksi. Dan semakin banyak mereka merokok maka semakin tinggilah resiko terkena disfungsi ereksi. Para pria yang mengkomsumsi rokok lebih dari 20 batang/ hari mengalami peningkatan resiko disfungsi ereksi berkisar sampai 39\%.9 Dan pada penelitian yang dipublikasikan oleh Dr. Larry Lipshultz, kepala pengobatan reproduksi pria di Baylor Collage of Medicine di Houston AS, mengatakan bahwa kebiasaan merokok dapat menyebabkan penyempitan pembuluh darah sehingga merupakan penyebab utama dari disfungsi ereksi selain penyebab disfungsi ereksi lainnya yaitu obesitas, komsumsi alcohol berlebihan dan penyalahgunaan narkoba. ${ }^{2}$

\section{SIMPULAN}

Petugas keamanan di Universitas Udayana Sudirman dengan kebiasaan merokok hampir seluruhnya mengalami disfungsi ereksi dengan kategori yang berbeda terhadap kejadian disfungsi ereksinya.

\section{KONFLIK KEPENTINGAN}

Penulis menyatakan tidak terdapat suatu konflik kepentingan terhadap publikasi dari artikel ini.

\section{PENDANAAN}

Penelitian ini tidak mendapatkan suatu pendanaan yang diberikan oleh pemerintah ataupun lembaga swasta lainnya.

\section{KONTRIBUSI PENULIS}

Konsep penelitian: Putu Gede Pradipta Mahardika Wijaya, Ida Ayu Sri Wijayanthi, Ketut Widyastuti. Pengumpulan data, input data dan pengolahan data: Putu Gede Pradipta Mahardika Wijaya. Penyusunan naskah Penelitian: Putu Gede Pradipta Mahardika Wijaya.

\section{ETHICAL CLEARANCE NUMBER}

2475/UN.14.2.2.VII.14/LP/2018.

\section{DAFTAR PUSTAKA}

1. Syarfa Ilyati. Gambaran Tingkat Pengetahuan, Perilaku Merokok Dan Nikotin Dependen Mahasiswa Uin Syarif Hidayatullah Jakarta. Program Studi Ilmu Keperawatan Fakultas Kedokteran Dan Ilmu Kesehatan Universitas Islam Negeri Syarif Hidayatullah Jakarta. 2015.

2. Hasan. S. M. Nurbaiti, Tendean Lydia, Wantouw Benny. Pengaruh Merokok Terhadap Fungsi Ereksi Pria. Jurnal e-Biomedik (eBm) kadidat skripsi fakultas kedokteran Universitas Sam Ratulangi Manado. 2015. Vol. 3: 1.

3. Rusdi S, Turalaki G, Satiawati L. Hubungan Antara merokok dengan terjadinnya disfungsi ereksi pada sopir angkutan umum di terminal karombasan Manado. Bagian Biologi Fakultas Kedokteran Universitas Sam Ratulangi Manado. 2016. Vol. 4 (2).

4. Kim DE. Erectile Dysfunction Differential Diagnoses. Department of Urology, University of California Los Angeles, David Geffen School of Medicine. 2018.

5. Mayo Clinic Staff. Erectile Dysfunction. Mayo Clinic. [online]. 2018. Tersedia di https://www.mayoclinic. org/diseases-conditions/erectile-dysfunction/symptoms-causes/syc-20355776 [diunduh: 30 januari 2019]

6. Turalaki G. Hubungan Antara Suhu Dan Konsumsi Minuman Beralkohol Dengan Terjadinya Disfungsi Ereksi Pada Sopir Angkutan Umum di Terminal Paal Dua Kota Manado Tahun 2014. Fakultas kedokteran Universitas Sam Ratulangi Manado. 2015.Vol. 5: 2.

7. Jeanne B. Prevalensi konsumsi rokok pria usia $18-64$ tahun dengan hipertensi di desa susut, kabupaten bangli bali tahun 2014. Intisari Sains Medis. 2016. 6(1): 16-22. DOI:10.15562/ism.v6i1.15.

8. Sitepoe M. Kekhususan Rokok di Indonesia. Jakarta: Gramedia Widiasarana Indonesia; 2000.

9. YogiantoroMm. Hipertens Esensial Dalam Buku Ajar Ilmu Penyakit Dalam Jilid I edisi IV. Jakarta: FK UI 2006.

10. BMJ Specialty Journals. Male Smokers 40 Percent More Likely to be Impotent than non-smokers. Smoking and erectile dysfunction: findings from a representative sample of Australian men; tabacco control. 2006. 15: 136-9.

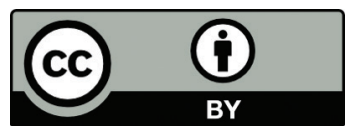

This work is licensed under a Creative Commons Attribution 